\title{
Efficacy of Arogyavardhini vati with prakshalan of kshirivriksha in management of karnasrava
}

\author{
Research Article
}

\begin{abstract}
Shukla Rakesh $\mathbf{R}^{1^{*}}$, Verma Ajit $\mathbf{S}^{2}$, Mishra Preeti ${ }^{3}$
1. Lecturer, Dept of Swasthavritta Sri Ganganagar college of Ayurvedic science Rajasthan,

2. Lecturer, Dept of Samhita Uttaranchal Ayurvedic College Dehradun,

3. BAMS (Intern) BVDU, Pune
\end{abstract}

\begin{abstract}
Background: Now a days there is a lot of change in the life styles of peoples. Also due to increasing number of vehicles with their different types of sounds of horns leads to sound pollution which affects the ear. Thus due to different Apathyakar Ahar Vihar there is development of different types of Karnarogas. Karnasrava is alone among commonly found Karna Rogas now a days, resembles with otorrhoea, acute otitis externa and chronic otitis media. These diseases lead to permanent hearing loss, so it is necessary to treat properly. In modern practice these diseases are treated by systemic as well as local Antibiotics, Analgesics and Anti-inflammatory drugs. This affects the economical status of the patient. So it needs cheap treatment. Aim: Efficacy of Arogyavardhini Vati with Prakshalan of Kshirivriksha in management of Karnasrava. Conclusion: Karnasrava was found to be more prevalent in the lower strata of the society and labor class workers. The classical textual benefits of Arogyavardhini Vati with Panchkshiri Kwatha Prakshalan were adopted. This Vati is easily available \& cheap conservative line of treatment for Karnasrava. This Vati used for longer duration may prove more effective in Karnasrava.
\end{abstract}

Key words: Karnasrava, Otorrhoea, Arogyavardhini vati, Kshiri vriksha,

\section{Introduction:}

Karna is considered as one of the 9 Dwaras and is considered as one among the Panchendriyas. (1) It is known as Shrotrendriya. Main function of ear is the perception of Sound. Along with function of hearing, it maintains the equilibrium of body.

Now a day there is a lot of change in the life styles of peoples. Very cold

\section{*Corresponding Author:}

\section{Shukla Rakesh R,}

Lecturer, Dept of Swasthavritta

Sri Ganganagar college of Ayurvedic science, Rajasthan

Email: drrakesh.ayur@gmail.com

Phone No: +91-8888556148 foods like ice-cream, cold drinks have an increasing demand. Consumption of such products will leads to vitiation of Doshas. Also due to increasing number of vehicles with their different types of sounds of horns leads to sound pollution which affects the ear. Thus due to different Apathyakar Ahar Vihar there will be development of different types of Karnarogas.(2)

Karnasrava is one among the 28 Karnarogas described by Acharya Sushruta.(3) Vagbhata has not mentioned Karnasrava as a separate disease but has explained about Karnasrava Chikitsa.

According to modern science otorrhoea, acute otitis externa and chronic otitis media are the commonly available 
diseases in most of the peoples now days. A clinical feature of Karnasrava resembles with otorrhoea, acute otitis externa and chronic otitis media. These diseases lead to permanent hearing loss, so it is necessary to treat properly. In modern practice these diseases are treated by systemic as well as local Antibiotics, Analgesics and Antiinflammatory drugs. But recurrences are very common. Long term antibiotics, while they decrease rates of infection during treatment, have an unknown effect on long term outcomes such as hearing loss. (4) It require surgical line of treatment i.e. Tympanoplasty etc. This again affects the economical status of the patient. So it needs cheap treatment.

Hence an effective treatment approach, which is simple and economical, needs a serious consideration. In Karnasrava there is vitiation of Tridosha. In this Pitta leads to melting of Kapha which discharges out through the external auditory canal. Vata associates with pain in this disease so mainly Tridoshaghna treatment is required.

Arogyavardhini Vati has different ingredients which reduce the Karnasrava. This drug is easily available and also cost of it is very less. So the persons who are living in low socioeconomic family they can also be prevented from this disease. According to Rasaratna Samucchaya mentioned that Arogyavardhini Vati has Sarvaroga Prashamani.(5) Kshiri Vriksha having Kashaya Rasa (Udumbara having Madhura as Anurasa), Shita Virya do Kapha Pitta Shamana and Karma like Shothahara, Vedanasthapana, Vranashodhana and Vranaropaka. (6) Prakshalan with Kshirivriksha Kashaya is described by Acharya Sushruta in Karnaroga Pratishedha. (7)
Aims:

Efficacy of Arogyavardhini Vati with Prakshalan of Kshirivriksha in management of Karnasrava.

\section{Methodology:}

Study design:

Clinical prospective experimental comparative single blind study - Entire study is based on clinical findings and patient's narration. Total 60 patients were selected, and divided randomly into two groups as experimental group and control group.

\section{Experimental group:}

The patients were treated with Arogyavardhini Vati 500mg thrice a day with Sharkarayukta Jala and Pramarjana with Panchkshiri Kwatha.

\section{Control group:}

The patients were treated with cap Amoxicillin 500mg thrice a day and aural toilet with dry cotton swab.

\section{Selection of drug:}

Arogyavardhini Vati Purchased from market of a good brand Divya Pharmacy.

\section{Contents of Arogyavardhini Vati (8)}

- Parad-1 part

- Gandhak-1 part

- Tamra bhasma-1 part

- Abhrak bhasma-1 part

- Shilajit-3 parts

- Triphala churna-2 parts

- Chitrakmula churna-4 parts

- Guggulu-4 parts

- Katuki churna-18 parts

- Bhavana dravya-Nimba vrikshadalarasa-72 parts

Kshirivriksha: (6) (9)

1. Vata - Ficus bengalensis Linn.

2. Asvatha-Ficus religiosa Linn.

3. Udumber - Ficus racemosa Linn.

4. Plaksha-Ficus lacor Linn.

5. Parisha - Thesposia populnea (Linn) soland 
Preperation of Kshirivruksha kwatha:

Kshirivriksha churna 1 part +16 parts Jala + reduced to $1 / 8^{\text {th }}$ part (10)

\section{Procedure:}

Dry sterile cotton swab-apply to Shalaka- dipped in Triphala Kwathacleaned the ear canal.

\section{Inclusion Criteria:}

1. The patients having signs and symptoms of Karnastrava like,

2. Discharge through the ear

3. Itching in the ear

4. Pain in ear

5. Tenderness at the periphery of the ear

6. Irrespective of Age, Sex, Religion was selected for the project.

7. Patients in age group of 5-60 yrs.

\section{Exclusion Criteria:}

1. Patients with recent ear operation.

2. Patients above 60 yrs of age

3. Congenital anomalies of eye

4. Patients having Diabetes mellitus

5. Pregnant women

6. Patients with Acute suppurative otitis media

\section{Follow ups:}

Follow up of these patients was taken on $1^{\text {st }}, 3^{\text {rd }}, 5^{\text {th }}, 7^{\text {th }}, 9^{\text {th }}, 11^{\text {th }}, 13^{\text {th }}$, $15^{\text {th }}$ day.

\section{Parameter:}

1. Ear discharge:

Grade 0 Normal

Grade 1 Mild - scanty secretion near tympanic membrane

Grade 2 Moderate - secretions irrigating in the ear canal

Grade 3 Severe - secretion coming out of ear canal.

Kandu, Shula and tenderness are measured by visual analogue score (VAS).

Figure 1: Visual Analogue Scale (VAS)

\begin{tabular}{|c|c|c|c|c|c|c|c|c|c|}
\hline † & 7 & 7 & $T$ & 1 & $T$ & $T$ & 7 & $T$ & $T$ \\
\hline 0 & 1 & 2 & 3 & 4 & 5 & 6 & 7 & 8 & 9 \\
\hline
\end{tabular}

2. Kandu (Itching)

Grade $0 \quad$ - Normal (0-1)

Grade $1 \quad$ - Mild (2-4)

Grade 2 - Moderate (5-7)

Grade 3 - Severe (8-10)

3. $\quad$ Pain (Karnashula)

Grade $0 \quad$ - Normal (0-1)

Grade $1 \quad$ - Mild $\quad(2-4)$

Grade 2 - Moderate (5-7)

Grade $3 \quad$ - Severe $\quad(8-10)$

4. Tenderness:

Grade $0 \quad$ - Normal (0-1)

Grade 1 - Mild (2-4)

Grade 2 - Moderate (5-7)

Grade $3 \quad$ - Severe (8-10)

Criteria for assessment of overall responses

Based on the changes in the signs and symptoms the cure rate was classified into

Good

response

Moderate

response

Mild response

No relief
- Above $76 \%$ relief in overall features.

- $51 \%$ - $75 \%$ relief in overall features.

- $26 \%-50 \%$ relief in overall features

- Below 25\% relief in overall features. 


\section{Observation:}

Data analysis consisted of two parts, first part to describe the characteristic of the study subjects by using descriptive methods viz. general points like age, sex, prakruti etc. second part consisted of comparisons of pre treatment measurements of the outcome with that of post treatment measurements where we used inferential methods and statistics. Statistical analysis was done for the results using student $t-$ test at $5 \%$ level of significance.

\section{Distribution of patient According to Age:}

Table 1: Distribution according to Age

\begin{tabular}{|c|c|c|c|c|}
\hline \multirow[t]{2}{*}{ Age } & \multicolumn{2}{|l|}{ Trial } & \multicolumn{2}{|l|}{ Control } \\
\hline & No. of Patients & Percentage & No. of Patients & Percentage \\
\hline $15-25$ & 15 & $50 \%$ & 2 & $6.67 \%$ \\
\hline $25-35$ & 11 & $36.67 \%$ & 11 & $36.67 \%$ \\
\hline $35-45$ & 4 & $13.33 \%$ & 12 & $40 \%$ \\
\hline $45-55$ & 0 & $0 \%$ & 5 & $16.66 \%$ \\
\hline Total & 30 & $100 \%$ & 30 & $100 \%$ \\
\hline
\end{tabular}

Distribution of the patients according to Sex

Table 2: Distribution according to Sex

\begin{tabular}{|c|c|c|c|c|}
\hline \multirow[t]{2}{*}{ Sex } & \multicolumn{2}{|l|}{ Trial } & \multicolumn{2}{|l|}{ Control } \\
\hline & No. of Patients & Percentage & No. of Patients & Percentage \\
\hline Male & 13 & $43.33 \%$ & 15 & $50 \%$ \\
\hline Female & 17 & $56.67 \%$ & 15 & $50 \%$ \\
\hline Total & 30 & $100 \%$ & 30 & $100 \%$ \\
\hline
\end{tabular}

Distribution according to Prakruti of Patients:

Table 3: Distribution according to Prakruti

\begin{tabular}{|l|l|l|l|l|}
\hline \multirow{2}{*}{ Prakruti } & \multicolumn{2}{|l|}{ Trial } & Control \\
\cline { 2 - 5 } & No. of Patients & Percentage & No. of Patients & Percentage \\
\hline Vata-Kapha & 16 & 53.33 & 14 & 46.67 \\
\hline Pitta-Kapha & 05 & 16.67 & 6 & 20 \\
\hline Vata-Pitta & 09 & 30.00 & 10 & 33.33 \\
\hline Total & 30 & $100 \%$ & 30 & $100 \%$ \\
\hline
\end{tabular}

Distribution according to laterality

Table 4: Distribution according to Laterality

\begin{tabular}{|l|l|l|l|l|}
\hline \multirow{2}{*}{ laterality } & \multicolumn{2}{|l|}{ Trial } & Control \\
\cline { 2 - 5 } & No. of Patients & Percentage & No. of Patients & Percentage \\
\hline Unilateral & 19 & $63.34 \%$ & 17 & $56.67 \%$ \\
\hline Bilateral & 11 & $36.63 \%$ & 13 & $43.33 \%$ \\
\hline Total & 30 & $100 \%$ & 30 & $100 \%$ \\
\hline
\end{tabular}


Statistically analysis on result of Srava

Table 5: Statistically analysis on result of Srava

\begin{tabular}{|c|c|c|c|c|c|c|c|}
\hline Group & \multicolumn{2}{|c|}{ Mean } & SD & $\%$ of relief & t cal & t table & $\mathrm{P}$ value \\
\hline \multirow{2}{*}{ Trial } & BT & 2.67 & \multirow{2}{*}{0.85} & $81.27 \%$ & \multirow{2}{*}{15.71} & \multirow{2}{*}{2.45} & \multirow{2}{*}{$<0.0001$} \\
\hline & AT & 0.5 & & & & & \\
\hline \multirow{2}{*}{ Control } & BT & 2.93 & \multirow{2}{*}{0.78} & $76.01 \%$ & \multirow{2}{*}{13.32} & \multirow{2}{*}{2.45} & \multirow{2}{*}{$<0.0001$} \\
\hline & $\overline{\text { AT }}$ & 0.7 & & & & & \\
\hline
\end{tabular}

Table no 5 shows the effect on Srava, Both control and trial group has shown statistically significant result $(\mathrm{p}<0.05)$.

Statistically analysis on result of Kandu

Table 6: Statistically analysis on result of Kandu

\begin{tabular}{|c|c|c|c|c|c|c|c|}
\hline \multirow{2}{*}{\multicolumn{3}{|c|}{\begin{tabular}{|l|l} 
Group & Mean
\end{tabular}}} & \multirow{3}{*}{ SD } & \multirow{3}{*}{$\begin{array}{l}\% \\
75.26\end{array}$} & \multirow{4}{*}{$\frac{t \text { cal }}{16.35}$} & \multirow{4}{*}{$\begin{array}{l}\text { t table } \\
2.45\end{array}$} & \multirow{4}{*}{$\begin{array}{l}\mathrm{P} \text { value } \\
<0.0001\end{array}$} \\
\hline & & & & & & & \\
\hline \multirow{2}{*}{ Trial } & BT & 2.83 & & & & & \\
\hline & AT & 0.7 & 0.65 & & & & \\
\hline \multirow{2}{*}{ Control } & BT & 2.43 & \multirow{2}{*}{0.92} & \multirow[t]{2}{*}{71.19} & \multirow{2}{*}{9.05} & \multirow{2}{*}{2.45} & \multirow{2}{*}{$<0.0001$} \\
\hline & AT & 0.7 & & & & & \\
\hline
\end{tabular}

For Kandu both Trial and control group has shown statistically significant results, $\mathrm{p}$ value is $<0.05$ for both groups.

Statistically analysis on result of Karnashula

Table 7: Statistically analysis on result of Shula

\begin{tabular}{|l|l|l|l|l|l|l|l|}
\hline Group & \multicolumn{2}{|l|}{ Mean } & SD & $\%$ & t cal & t table & P value \\
\hline \multirow{2}{*}{ Trial } & BT & 2.86 & \multirow{2}{*}{0.60} & 66.89 & \multirow{2}{*}{12.35} & 2.45 & $<0.0001$ \\
\cline { 2 - 8 } & AT & 0.9 & & & 72.44 & & \\
\hline \multirow{3}{*}{ Control } & BT & 2.54 & \multirow{2}{*}{0.77} & & 7.79 & 2.45 & $<0.0001$ \\
\cline { 2 - 8 } & AT & 0.7 & & & & & \\
\hline
\end{tabular}

Above statistically analysis on Karnashula shows both groups are statistically significant.

Statistically analysis on result of Sparsha Asahishnuta (Tenderness)

Table 8: Statistically analysis on result of Sparsha Asahishnuta

\begin{tabular}{|c|c|c|c|c|c|c|c|}
\hline Group & \multicolumn{2}{|c|}{ Mean } & SD & $\%$ & $\mathrm{t}$ cal & $\mathrm{t}$ table & P value \\
\hline \multirow{2}{*}{ Trial } & BT & 2.90 & \multirow{2}{*}{0.55} & \multirow[t]{2}{*}{61.37} & \multirow{2}{*}{12.43} & \multirow{2}{*}{2.45} & \multirow{2}{*}{$<0.0001$} \\
\hline & $\mathrm{AT}$ & 1.12 & & & & & \\
\hline \multirow{2}{*}{ Control } & BT & 2.69 & \multirow{2}{*}{0.71} & \multirow[t]{2}{*}{77.69} & \multirow{2}{*}{6.85} & \multirow{2}{*}{2.45} & \multirow{2}{*}{$<0.0001$} \\
\hline & AT & 0.6 & & & & & \\
\hline
\end{tabular}

Result of control group shows more relief. Both groups are statistically significant. 
Discussion:

Karnasrava:

Karna is one of the most important Gyanendriya in body. Its important function is hearing. It is also important organ in maintaining balance of body.

Samanya nidan:

Avashyaya (excessive expose to cold), Jala Krida (Excessive swimming), Karna kanduryanam (Scratching), Shabda mithyayoga, Abhighata, Vitiatian of Tridosha. (2) After study it is observed that the patients having the habits of icecreams, cold drinks \& who exposed to pollution are more prone to this disease.

\section{Samprapti:}

Due to etiological factors the vitiated Doshas gets Sthansamshraya in Karna and cause Karnasrava.

\section{Sampraprti ghatak:}

\begin{tabular}{|l|ll|}
\hline Dosha & Predominently Vata \\
\hline Dushya & Rasa, Rakta, Mamsa & \\
\hline Srotas & Shabdavaha \\
\hline Srotidusti & $\begin{array}{l}\text { Sanga, Vimarga gaman, } \\
\text { Atipravruti }\end{array}$ \\
\hline Adhisthan & Karna \\
\hline
\end{tabular}

Rupa:

The Lakshanas of Karnasrava can be correlated with otorrhoea (mucoid or mucopurulent). Only Puyasrava is mentioned as symptoms but here Puyasrava refers to different nature of discharge like Jalasrava, Rasasrava which can be considered as watery, mucopurulent and purulent discharge.

\section{Sadhya-asadhyata:}

Sadhyata gives the clear picture of prognosis of the disease. It depends on many factors like nature of disease, severity of disease, Vaya, Prakruti, Bala of Patient etc. Sushruta has not mentioned specifically the Sadhya-asadhyata of the Karnarogas. But Vagbhata has mentioned Karnasrava as a Sadhyavyadhi. (11)
Discussion on observation: Age wise distribution:

Patients of age group 15-25 years are more prone to this disease because of different food habits and exposure to cold atmosphere.

\section{Sex wise distribution:}

Incidence of Karnasrava observed more in females in both group.

\section{Prakruti wise distribution:}

It shows Vata predominant individuals are more predisposed to Karnasrava.

\section{Laterality:}

Although Karnasrava can be unilateral or bilateral, in the present study, out of 60 patients 36 had unilateral involvement and 24 had bilateral involvement.

\section{Discussion on result: \\ Discharge from Ear:}

Both groups are statistically significant but when we show percentage of relief, Trial group has shown little bit more relief. Possibility for that, Arogyavardhini Vati does the Shoshan of different excess Snigdha Dravyas present in the ear.

\section{Kandu:}

Kandu was relieved in most of the patients. In Kandu Trial group who were taken Arogyavardhini Vati, has shown good result comparatively.

\section{Karnashula:}

Control group has shown $72.44 \%$ relief while, Trial group has shown 66.89 $\%$ relief. Here Patients who had followed Tab Amoxicillin has shown better results than Tab Arogyavardhini Vati.

\section{Sparshasahishnuta:}

Trial group has shown $61.37 \%$ relief while control group has shown $77.69 \%$ relief. Arogyavardhini Vati does Pachan of Doshas and Kleda. 


\section{Overall result:}

In Trial group, $43.33 \%$ patients have shown good response, $56.67 \%$ shown moderate response. While in Control group, $41.56 \%$ have shown good response, $52 \%$ moderate response and $6.44 \%$ have shown mild response.

\section{Possible Mode of Action}

Arogyavardhini Vati does the Shoshan of different excess Snigdha Dravyas present in the ear. It also does the Pachan of Drava and Kled and does the Raktavardhan. It reduces Dravatva, Snigdhatva in Meda Dhatu. According to Panchmahabhoutikata Karnasrava having Prithvi and Jala Mahabhuta Pradhan, while Arogyavardhini vati has Akash, Vayu, and Teja Mahabhuta Pradhanata. Due to these Mahabhuta Pradhanata it is helpful to reduce the Karnasrava.

As Kshiri Vriksha are having Kashaya Rasa, Ruksha Guna and Kapha Pittaghna properties, it removes the aggravated Kapha and Pitta Guna and thus helps in reducing Srava, Kandu, pain and tenderness from ear.

\section{Conclusion}

Karnasrava was found to be more prevalent in the lower strata of the society and labor class workers. The classical textual benefits of Arogyavardhini Vati with Panchakshiri Kwatha Prakshalan were adopted. This Vati is easily available $\&$ cheap conservative line of treatment for Karnasrava. This Vati used for longer duration may prove more effective in Karnasrava. Arogyavardhini Vati and Kshirivriksha Prakshalan are equally effective and comparatively cheap and safe to use.

\section{References}

1. Murthy KRS. Sushruta Samhita. Vol2, Sharira sthana 5/10, Varanasi; Chaukhambha Oreintalia; 2004. Pp- 81
2. Tripathi Brahmanand. Astanga Hridayam. Uttara sthana 17/1-3, Delhi; Chaukhambha Sanskrit Pratishthan; 2007. Pp- 998

3. Shastri Ambikadutt. Sushruta Samhita. Part-2, Uttara Sthana 20/5, Varanasi; Chaukhambha Sanskrit Sanshthan; 2006. Pp- 86

4. Leach AJ, Morris PS (2006). "Antibiotics for the prevention of acute and chronic suppurative otitis media in children". In Leach, Amanda J. Cochrane Database Syst Rev(4): CD004401.

5. Tripathi Indradev. Rasaratna Samuchchaya. 20/93, $3^{\text {rd }}$ ed., Varanasi; Chaukhambha Sanskrit Bhawan; 2006. $\mathrm{Pp}-252$

6. Mishra Brahma Shankar. Bhavprakasha Nighantu. Vatadi varga 115-16, 11th ed., Varanasi; Chaukhambha Sanskrit Bhawan; 2004. Pp - 519

7. Shastri Ambikadutt. Sushruta Samhita. Part -2, Uttara Sthana 21/42, Varanasi; Chaukhambha Sanskrit Sanshthan; 2006. Pp- 101

8. Tripathi Indradev. Rasaratna Samuchchaya. $20 / 86-92, \quad 3^{\text {rd }}$ ed., Varanasi; Chaukhambha Sanskrit Bhawan; 2006. Pp - 252

9. Sharma P.V. Dravyaguna Vigyanam. Vol-2, Varanasi; Chaukhambha Bharati Academy; 2005. Pp-664-670

10. Shastri Hari Sadashiv. Astanga Hridaya. Kalpa Sthana 6/13-14, Varanasi; Chaukhambha Sanskrit Pratishthan; 2012. Pp 773

11. Tripathi Brahmanand. Astanga Hridayam. Uttara sthana 17/1-3, Delhi; Chaukhambha Sanskrit Pratishthan; 2007. Pp- 998

12. Tripathi Brahmanand. Astanga Hridayam. Uttara sthana 17/25-26, Delhi; Chaukhambha Sanskrit Pratishthan; 2007. Pp- 1003 